\title{
Does Age Matter? Estimating Risks of Locoregional Recurrence After Breast-conservative Surgery
}

\author{
GIANLUCA VANNI ${ }^{1}$, MARCO MATERAZZO ${ }^{1}$, MARCO PELLICCIARO $^{1}$, LJUBA MORANDO $^{1}$, \\ ILARIA PORTARENA ${ }^{2}$, LUCIA ANEMONA ${ }^{3}$, MARIA ROLANDO D'ANGELILLO ${ }^{4}$, ROSARIA BARBARINO $^{4}$, \\ AGOSTINO CHIARAVALLOTI $^{5,6}$, ROSARIA MEUCCI ${ }^{1,7}$, TOMMASO PERRETTA $^{7}$, CAMILLA DEIANA ${ }^{1}$, \\ PAOLO ORSARIA ${ }^{8}$, JONATHAN CASPI $^{1}$, CHIARA ADRIANA PISTOLESE $^{7}$ and ORESTE CLAUDIO BUONOMO ${ }^{1}$ \\ ${ }^{1}$ Breast Unit - Department of Surgical Science, Policlinico Tor Vergata University, Rome, Italy; \\ ${ }^{2}$ Department of Oncology, Policlinico Tor Vergata University, Rome, Italy; \\ ${ }^{3}$ Anatomic Pathology, Department of Experimental Medicine, Policlinico Tor Vergata University, Rome, Italy; \\ ${ }^{4}$ Radiotherapy Unit, Department of Oncology and Hematology, Policlinico Tor Vergata University, Rome, Italy; \\ ${ }^{5}$ Department of Biomedicine and Prevention, Policlinico Tor Vergata University, Rome, Italy; \\ ${ }^{6}$ IRCCS Neuromed, UOC Medicina Nucleare, Pozzilli, Italy; \\ ${ }^{7}$ Department of Diagnostic Imaging and Interventional Radiology, \\ Molecular Imaging and Radiotherapy, Policlinico Tor Vergata University, Rome, Italy; \\ ${ }^{8}$ Department of Breast Surgery, University Campus Bio-Medico, Rome, Italy
}

\begin{abstract}
Background/Aim: In 2016, in the United States, more than $50 \%$ of breast cancer $(B C)$ cases were diagnosed in patients older than 60 years of age. Our study aimed to estimate the risk of locoregional recurrence (LR) in patients who underwent breast-conservative treatment (BCT), according to age. Patients and Methods: This retrospective monocentric study analyzed 613 cases of patients who underwent BCT between 2003 and 2014. Patients were divided into groups according to age: Under70 (under 70 years old) and Over70 (above 70 years old). Margins width, histology results, prognostic and predictive factors were compared. Subgroup analysis was performed for patients who experienced LR. Results: LR Incidence among Under 70 and Over70 was $5.4 \%$ and $1.7 \%$, respectively $(p<0.01)$. Group Over70 is characterized by larger tumors and a lower Ki67 index $(p<0.01)$. Conclusion: Operation time reduction, better aesthetic results and reduced LR risk support BCT. The Over70 group exhibited better outcomes in terms of $L R$ despite larger tumor dimensions.
\end{abstract}

This article is freely accessible online.

Correspondence to: Marco Materazzo, Breast Unit - Department of Surgical Science, Policlinico Tor Vergata (PTV) University, Viale Oxford 81, 00133 Rome, Italy. Tel: +39 3395685883, e-mail: mrcmaterazzo@gmail.com

Key Words: Breast cancer, breast-conservative treatment, breast cancer, elderly, tailored treatment.
Recent research of global cancer concludes that breast cancer (BC) represents the second most common cause of neoplasms with an overall number of more than 2 million cases worldwide (1). Demographic transition in developed countries predetermines increase in life expectancy and growth of the elderly population. Consequently, the growing numbers of $\mathrm{BC}$ diagnosis in aged patients point out the importance of a tailored approach even in this target population, avoiding undertreatment (2-4). Moreover, it is demonstrated that age is a strong factor influencing patient's choice of refusing surgery, with other demographic and disease-specific characteristics (5). In 2016, more than $50 \%$ of BCs were diagnosed in patients older than 60 years (6). Surgical management of BC is divided into two approaches: Mastectomy $(\mathrm{Mx})$ and breastconservative treatment $(\mathrm{BCT})(7,8)$.

Mx consists of breast gland complete removal with the possibility of sparing the Nipple Areola complex $(9,10)$. Breast reconstruction (BR) should be considered and offered to patients who undergo mastectomy, if not contraindicated by performance status or clinical stage of disease (11-13). Modern conception of breast surgery treatment shifts from preserving the breast appearance specifically to improvement of the general body image through an oncoplastic surgical technique $(10,14)$. BR can be performed through several techniques including lipofilling, myo-cutaneous autologous flaps and prosthetic implants $(15,16)$. Breast implants represent the first preference in $81.2 \%$ of cases (17). Between the years 2014 and 2018 the rate of Mx following immediate BR increased from $6.7 \%$ to $18.1 \%$ in women 65 years old or older (18). With that said, patients older than 65 
are less likely to undergo BR compared to younger patients (19). Moreover, in large series, elderly patients showed a higher rate of early complications and risk of thirty-day unplanned readmission, particularly when BR was performed with an implant-based technique (18-20). Furthermore, social norms regarding sexuality, ageing and patients' priority certainly play a role in reducing the rate of BR procedure in this subset of patients $(19,21)$. Fenlon et al., found that BR was rarely mentioned to patients over 70 years old (22). On the other hand, avoidance of oncological radiation therapy (RT) in early breast cancer constitutes a daily clinical practice advantage of Mx. Due to these reasons and the frailty of older patients, BR is not offered to these patients as frequently as it is for younger population.

BCT includes partial removal of the mammary gland (Breast Conservative Surgery [BCS]) and subsequent adjuvant RT (23-25). Reduction of surgery duration, smaller scar, lower complication rate and shorter recovery after surgery are the major advantages of BCT (8). In addition, BCS could offer synergism to Enhanced Recovery After Surgery program, which combines nerve block analgesia, needle wire localization and probe-guided surgery, to allow day surgical management in selected patients $(14,26-32)$. BCT is well accepted by women and shows better outcomes for sexual and psycho-social well-being, as well as breast satisfaction compared to unilateral and bilateral $\mathrm{Mx}$ (33).

Nevertheless, side-effects of BCT consist of scaring, skin changes, poor aesthetic result, reoperation due to insufficient margin width and locoregional recurrence (LR). Adjuvant RT can cause skin tenderness and potential long-term effects of radiotherapy namely arm pain and lung damage $(34,35)$. Since 2014, in order to reduce Reoperation Rate (ROR), the Society of Surgical Oncology (SSO) and the American Society for Radiation Oncology (ASTRO) developed consensus guidelines defining negative margins as "No Ink on Tumor" and as $2 \mathrm{~mm}$ for BC and ductal carcinoma in situ (DCIS), respectively $(36,37)$. According to current guidelines, wider negative margins are not linked to better locoregional control of disease and thus further procedures are no longer recommended.

Margin management is linked with aesthetic results through the correlation between the extent of surgery and consequential breast appearance. Percentage of volume excision and localization of $\mathrm{BC}$ in the mammary mold are well known factors affecting breast postoperative shape (38). In case of extensive surgery, oncoplastic procedures (OPS) may improve aesthetic results described as "fair" or "poor" (14).

LR is a pathological condition characterized by reappearance of tumors in the ipsilateral breast, usually in the same quadrant of the primary tumor (70-75\% of cases). Immunophenotypic and histological characteristics are mostly similar to the primary tumor, nevertheless, according to current data, LR may result in a less favorable course for the affected subjects $(39,40)$. Commonly, LR takes place within two years post primary treatment. These patients show higher risk for metastasis $(41,42)$. The incidence of LR is significantly decreasing: from $14.3 \%$ in the NSABP 06 study after 20 years of follow-up, to $3.5-6.5 \%$ in 1990 s (36-38). More recent evidence revealed an LR rate of 3.5\% (43-45) and $0.4 \%$ at 5 years (46). According to stage relapse, LR occurs in $20 \%$ of cases as a DCIS, while in the remaining $80 \%$ of cases as invasive BC. Moreover, in $75 \%$ of cases LR is unique and isolated to the breast, and in 5$15 \%$ is associated with lymph node recurrence or distant metastases $(47,48)$. In cases of LR, Mx is chosen as the first treatment, especially for elderly patients (49).

The modern era of $\mathrm{BC}$ treatment is headed by the knowledge of $\mathrm{BC}$ locoregional and metastatic behavior (50, 51) and the subsequent development of systemic tailored strategy, i.e. neoadjuvant chemotherapy (52-55). All these approaches together led to an increase in overall survival (OS) by $2.2 \%$ per year (56). The steady decrease in mortality predetermines an increasing number of patients in remission who are at risk of recurrence followed BCT. Overall growth of population at LR risk and demographic transition across the world raised attention to $\mathrm{BC}$ in the elderly $(2,57)$. Choices of treatment are debated during multidisciplinary meetings and, in order to minimize the risk of morbidity, adequate preoperative and frailty assessment with early involvement of the geriatrician and anesthetists should be performed (21). In our experience, due to the lower interest in aesthetics together with patients' anxiety, Mx without BR is the more common treatment requested by the elderly. In addition to lesser aesthetic results, $\mathrm{Mx}$ shows higher incidence of complications in comparison with BCT and even OPS. Mx alone, when associated with other comorbidities, may lead to unacceptable morbidity rates (58).

$\mathrm{BCT}$ is less invasive, requiring for shorter operation time with lower incidence of complications and could therefore produce good results, even in terms of LR, in elderly women. Our study aimed to compare LR among women of different age groups (younger than 70 and older than 70) who underwent BCT. Our hypothesis states that age has an impact over risks of LR, implying that BCT outcomes may be dependent on the patient's age.

\section{Patients and Methods}

Study design. This study is a retrospective case-control study. The Institutional Review Board of Policlinico Tor Vergata Foundation waived the need for a formal approval in view of the retrospective design of the study.

Patient characteristics. We examined all female patients who underwent oncological breast surgeries at the Breast Unit of Tor 
Table I. Linear correlation between age and $\% E R, P R$ and Ki67 index.

\begin{tabular}{lcccc}
\hline & Diameter mm & ER $\%$ & PR $\%$ & Ki67 \% \\
\hline Mean & $15(1-77)$ & $74.3(0-100)$ & $46.9(0-99)$ & $19.0(0-90)$ \\
R & 0.117 & 0.116 & 0.040 & 0.155 \\
\hline
\end{tabular}

Ki67: Proliferation index Ki67; ER; estrogen receptor; PR: progesterone receptor.

Vergata hospital (PTV). From January 2003 to December 2014 we analyzed 1,027 consecutive cases with a median age of 61 (range $=20-94$ years). All patients were admitted to and treated by the diagnostic and therapeutic facilities of PTV Breast Center in concordance with the Italian Association of Medical Oncology (AIOM) guidelines available in the period of treatment.

In line with the primary aim of the study, we analyzed only patients that received BCT, thus 613 patients (59.68\%). Median age of the cohort was 60 , mean follow-up was 85.56 months Recurrence was defined as disease relapse in the ipsilateral breast or ipsilateral axilla at 5 years follow-up. According to the main hypothesis of present study, we divided the studied population into two groups: patients who are older than 70 (Over70) and younger (Under70). We decided to use 70 years old patients as cut off considering the Italian Health Care System provides free mammogram screening to patients between the ages 50 and 69 (59). Moreover, the 70 years old cut off in the literature seems to affect the choice of treatment more than tumor biology (6). Table I represents summarized calculations of linear correlation between age and expression of estrogen receptor (ER), progesterone receptor (PR) and Ki67 index (Ki67) showing no correlation.

Data collection. Data from pathological examinations were analyzed regarding to the type of neoplasia, tumor dimension, surgical margin (in millimeters), node involvement, prognostic and predictive factors [ER, PR, Ki67 and human epidermal growth factor receptor 2 expression (HER2)]. Pathological staging was based on recommendations from AJCC 2018 (edition VIII) of TMN classification. Tumor Grade was evaluated according to the Nottingham Histologic Score system (the Elston-Ellis modification of Scarff-Bloom-Richardson grading system).

The ER, PR and Ki67 receptors were expressed as a percentage of positive cells in specimen studied through immunohistochemistry. Overexpression of Her2 gene (HER2 SCORE) was identified by IHC and by FISH, as indicated by the recommendations of the 2013 ASCO/CAP. Consequently, patients were classified as Her2-positive if they were assigned with $3+$ score by IHC or demonstrated the amplification of Her2 gene (ratio $>2$ ) by FISH. If the SCORE was not obtained through tests, it was blindly reevaluated by pathologist according to mentioned guidelines. All patients were divided into the following subgroups: Luminal A, Luminal B+, Luminal B-, Her2 Type (Her2), and Triple Negative in concordance with the classification of intrinsic subtypes recommended by the San Gallen International Expert Consensus Report of 2017. Outcomes of two groups were compared in terms of recurrence, pathological findings and relapse risk factors. After this primary analysis between Over70 and Under70 we subsequently analyzed the subgroup of patients who experienced LR.
Table II. Prognostic and predictive baseline findings in the study groups.

\begin{tabular}{lccr}
\hline & $\begin{array}{c}\text { Under70 } \\
(\mathrm{n}=435)\end{array}$ & $\begin{array}{l}\text { Over70 } \\
(\mathrm{n}=178)\end{array}$ & $p$-Value \\
\hline Tumor dimension (mm) & $14.4(1-77)$ & $17.0(1-67)$ & $<0.01$ \\
Surgical margin (mm) & $3.81(1-15)$ & $3.75(1-20)$ & 0.88 \\
Ki67 (\%) & $20.2(0-90)$ & $16.1(2-80)$ & $<0.01$ \\
ER (\%) & $72.6(0-100)$ & $78.6(0-95)$ & 0.04 \\
PR (\%) & $47.3(0-99)$ & $45.9(0-95)$ & 0.66 \\
\hline
\end{tabular}

Ki67: Proliferation index Ki67; ER: estrogen receptor; PR: progesterone receptor.

Statistical analysis. All data were codified into the EXCEL database (Microsoft, Washington, DC, USA). For continuous variables we calculated medians with ranges. Estimated dependent variables were continuous and not normally distributed. As a main statistical method, we used the Mann-Whitney $U$-test to compare differences between two independent groups (Over70 and Under70). Dummy variables were reported as numbers and percentages. Comparisons were performed using the Fisher's exact test. In order to identify relations between age and LR risks, we used Pearson correlation coefficient $(\mathrm{R})$. We measured the strength and direction of a linear relationship between age variable ( 0 if patient belongs to Over70 group, 1 if patient belongs to Under70 group) and LR variable (1 if LR presents, 0 if not). Coefficient values closer to -1 represent strong negative relationship, values closer to +1 show strong positive relationship. Values close to 0 imply weak or absent relationship. Variables with assigned $p$-values $<0.05$ were considered statistically significant. All the statistical analysis was performed in SPSS statistical package version 23.0 (SPSS Inc., Chicago, IL, USA).

\section{Results}

Among 613 patients who underwent BCS, the median follow-up was 4.63 years with $26(5 \%)$ cases of LR at pathological exam, $87,6 \%$ patients exhibited ductal carcinoma, $8 \%$ lobular carcinomas. Median dimensions of the tumors were $15 \mathrm{~mm}$, margins were $3.7 \mathrm{~mm}$ and in $22.51 \%$ of patients' node metastasis were documented. The group Under 70 contained 435 patients $(71 \%)$ and group Over70 178 patients (29\%). Tables II and III present summary statistics regarding status of receptors, Ki67 index and molecular subtype focusing, as well as $p$-values associated with ranks provided by the Mann-Whitney $U$-test.

No statistically significant difference was found regarding tumor subtypes, as summarized in Table III. Lymph node involvement presented in 40 cases $(22.5 \%)$ among the Over70 group and in 98 cases $(22.5 \%)$ among the Under70 group, our results demonstrated that age did not affect lymph node involvement $(p=0.828)$. Despite the discrepancy from known literature, the lack of differences between the groups could better highlight the impact of age on LR risk. 
Table III. Molecular subtype classification according San Gallen 2017 Criteria in the study groups.

\begin{tabular}{lccc}
\hline & $\begin{array}{c}\text { Under70 } \\
(\mathrm{n}=435)\end{array}$ & $\begin{array}{c}\text { Over70 } \\
(\mathrm{n}=178)\end{array}$ & $p$-Value \\
\hline LUMINAL A & $171(39 \%)$ & $66(37 \%)$ & 0.64 \\
LUMINAL B+ & $45(10 \%)$ & $24(13 \%)$ & 0.26 \\
LUMINAL B- & $138(31 \%)$ & $51(29 \%)$ & 0.50 \\
TRIPLE NEGATIVE & $33(7 \%)$ & $17(9 \%)$ & 0.17 \\
HER 2 & $139(31 \%)$ & $69(39 \%)$ & 0.11 \\
\hline
\end{tabular}

Her2-positive expression was found in 69 patients (38.8\%) among the group Over70 versus 139 cases (31.9\%) among the Under70 group $(p=0.11)$. Expression of ER was higher in older patients, $78.6 \%$ (Over70) versus $72.6 \%$ (under70 group), with a statistically significant difference $(p=0.04)$. Moreover, Ki-67 index demonstrated a statistically significant difference with higher values for younger group, $20.2 \%$ (Under70) and $16.1 \%$ (Over70) $(p=0.01)$. No difference in levels of PR was found between the groups $(p=0.66)$. Surgical margin widths were similar in both groups: $3.81 \mathrm{~mm}$ and $3.75 \mathrm{~mm}$ in Over70 and Under70, respectively $(p=0.88)$. Older patients exhibited higher tumor dimension median $(17.0 \mathrm{~mm})$ compared to that of the younger ones $(14.0 \mathrm{~mm})(p<0.01)$.

Incidence of LR were observed in $23(5.4 \%)$ cases among Under70 group and in $3(1.7 \%)$ cases among Over70 group, showing a statistically significant difference with $p=0.04$. Therefore, with regard to the hypothesis posed at the beginning of the study, it is now possible to state that age affects the BCS outcomes. General LR incidence constituted $4.2 \%$ of cases (26 out of 613 ). Subgroup analysis was performed with the same age cutoff, patients with LR in 23 cases belonged to Under70 group, and in 3 cases to Over70. Lymph node involvement was observed in 11 cases (47.8\%) among the younger group and in 1 case (33\%) among the older group (no statistically significant difference $p=1.000$ ). All older patients with LR showed Her2-positive expression compared to only 16 patients $(70 \%)$ in the younger group ( $p=0.53$ ). Expressions of ER and PR did not show any statistically significant difference between Over70 and Under70 groups ( $p=0.63$ and $p=0.95$, respectively). In addition, Ki-67 index was not statistically significantly different between groups, representing a median value of $24.2 \%$ in the Under70 and $25 \%$ in the Over70 study (associated $p=0.93$ ). Therefore, none of these differences were statistically significant. Older patients with LR showed larger tumour dimensions, $25.3 \mathrm{~mm}$ for Over70 versus 22.4 $\mathrm{mm}$ for Under70, and closer surgical margins $2.33 \mathrm{~mm}$ versus $2.51 \mathrm{~mm}$, without any statistical significance $(p=0.82$ and $p=0.87$, respectively).

\section{Discussion}

Comparing two groups of patients who relapsed, Over70 and Under70, we analyzed different predictive factors to identify which of them were the most relevant to relapse-onset. Our sample showed a $4.2 \%$ recurrence rate, in line with results of Kabat et al. (60).

Confirming existing research, our study showed that young patients experience recurrence more often than elderly patients $(61,62)$. Therefore, we proclaim that age is a fundamental variable of our study. Analyzing predictive factors between two groups we found that no statistically significant differences were found in terms of tumor subtype, unlike in literature, where tumors in the elderly are associated with a more favorable tumor biology (63). Even with regards to lymph node invasion we did not find any statistically significant difference between the two groups (64).

Furthermore, analysis of HER2 SCORE and PR expression did not show any statistical difference between groups. However, Under70 group presented higher value of both, as already underlined in the literature. HER2 SCORE and PR expression are both associated with recurrence (6568). Interestingly, patients in our series demonstrated no statistical difference on both factors underlying the role of age on LR risk.

Expression of ER was greater in older patients than in the Under70 group, showing a statistically significant difference, resulting as a protective factor for the onset of recurrence, consistent with literature (69). The Ki67 index also showed a statistically significant difference with a higher value among younger women, congruous with the literature (70). Interestingly, the study of margins showed larger dimensions in older patients than those Under70, without finding a statistically significant difference. Even though older patients showed larger tumor sizes than younger ones, with a statistically significant difference, in our study LR was lower in the elderly population. (71). Data presented in this article largely confirm data in the literature regarding the safety of $\mathrm{BCT}$, especially in the elderly, and the subsequent lower risk of LR in Over70 patients. The modern concept of negative margins is now defined as residual tumor burden low enough to be controlled by adjuvant treatment and not anymore associated with the assurance of no residual tumor burden in the breast $(34,72)$.

Surgical margins are not an exact science due to the high number of slices (up to 3,000 ) needed for a full evaluation of margin status and alteration of the specimen following surgical removal $(73,74)$. Moreover, tumor development could lead to multifocal, multicentric disease with residual neoplasm despite the negative margins of the surgical specimen (75). The correct surgical procedure could be selected through consideration of stage, biology of the tumor, 
adjuvant treatment, patient's expectations, performance status, patient's comorbidities as well as obtaining a correct surgical margin.

Our study demonstrated how LR rate could be affected by age, where Over70 patients experienced a lower rate. Our study has potential limitations mainly due to its retrospective design, single-center patients and the inability to calculate the percentage of volume excision in order to assess the aesthetic results. No information was collected in regard to the surgical techniques (e.g. OPS approach) and the adjuvant therapy due to the change made in breast cancer guidelines during the period of treatment. However, the length of the follow up, the lack of difference in Molecular subtypes rate and most of the prognostic and predictive factors can underline clearly the role of age in LR risk. The low rate of LR among the Over70 patients, largely confirmed from literature, signify the effectiveness of this approach in these subsets of patients.

In conclusion, our data, as largely known from literature, demonstrated that BCT is a safe procedure and should always be proposed in this group of patients in order to reduce the duration of surgery, the hospital stay and the complication rate. LR risk in elderly patients should not influence the surgical choice although maintenance of body integrity, even partial, should be considered. Further study could investigate the role of OPS in elderly patients in order to obtain margin-free and better aesthetic results. Moreover, discarding adjuvant treatment RT among these patients is debated in the literature. Potential abatement of RT highlights the importance of real communication between patients and the multidisciplinary team to allow the patients' full involvement in the therapeutic choice $(25,76)$.

\section{Conflicts of Interest}

The Authors declare no conflicts of interest regarding this study.

\section{Authors' Contributions}

Study conception and design: Pellicciaro Marco, Buonomo Oreste Claudio. Acquisition of data: Meucci Rosaria, Morando Ljuba, Anemona Lucia; Analysis of data: Marco Pelliccaro, Gianluca Vanni, Barbarino Rosaria; Interpretation of data: Materazzo Marco, Chiaravalloti Agostino; Article draft: Vanni Gianluca, Materazzo Marco, Caspi Jonathan; Critical revision: Perretta Tommaso, Orsaria Paolo; Critical Revision of Literature: Deiana Camilla, Pistolese Chiara Adriana, D’Angelillo Rolando Maria.

\section{References}

1 Ferlay J, Colombet M, Soerjomataram I, Mathers C, Parkin DM, Piñeros M, Znaor A and Bray F: Estimating the global cancer incidence and mortality in 2018: GLOBOCAN sources and methods. Int J Cancer 144: 1941-1953, 2019. PMID: 30350310. DOI: $10.1002 /$ ijc. 31937
2 Liotta G, Mancinelli S, Scarcella P, Pompei D, Mastromattei A, Cutini R, Marazzi MC, Buonomo E, Palombi L and Gilardi F: [Health and disability in the elderly: old paradigms and future prospects]. Ig Sanita Pubbl 68: 657-676, 2012. PMID: 23223317.

3 Varghese F and Wong J: Breast cancer in the elderly. Surg Clin North Am 98: 819-833, 2018. PMID: 30005776. DOI: 10.1016/ j.suc.2018.04.002

4 Pistolese CA, Lamacchia F, Tosti D, Anemona L, Ricci F, Censi M, Materazzo M, Vanni G, Collura A, DI Giuliano F, Perretta T and Buonomo OC: Reducing the number of unnecessary percutaneous biopsies: The role of second opinion by expert breast center radiologists. Anticancer Res 40: 939-950, 2020. PMID: 32014938. DOI: 10.21873/anticanres.14027

5 Restrepo DJ, Sisti A, Boczar D, Huayllani MT, Fishe J, Gabriel E, McLaughlin SA, Bagaria S, Spaulding A, Rinker BD and Forte AJ: Characteristics of breast cancer patients who refuse surgery. Anticancer Res 39: 4941-4945, 2019. PMID: 31519599. DOI: 10.21873 /anticanres.13682

6 Inwald EC, Ortmann O, Koller M, Zeman F, Hofstädter F, Evert $\mathrm{M}$, Brockhoff $\mathrm{G}$ and Klinkhammer-Schalke M: Screeningrelevant age threshold of 70 years and older is a stronger determinant for the choice of adjuvant treatment in breast cancer patients than tumor biology. Breast Cancer Res Treat 163: 119130, 2017. PMID: 28205042. DOI: 10.1007/s10549-017-4151-6

7 Sakorafas GH and Safioleas M: Breast cancer surgery: An historical narrative. Part III. From the sunset of the $19^{\text {th }}$ to the dawn of the 21st century. Eur J Cancer Care (Engl), 2010. PMID: 19674072. DOI: 10.1111/j.1365-2354.2008.01061.x

8 Veronesi U, Saccozzi R, Del Vecchio M, Banfi A, Clemente C, De Lena M, Gallus G, Greco M, Luini A, Marubini E, Muscolino G, Rilke F, Salvadori B, Zecchini A and Zucali R: Comparing radical mastectomy with quadrantectomy, axillary dissection, and radiotherapy in patients with small cancers of the breast. N Engl J Med 305: 6-11, 1981. PMID: 7015141. DOI: 10.1056/NEJM198107023050102

9 Halsted WS: I. A clinical and histological study of certain adenocarcinomata of the breast and a brief consideration of the supraclavicular operation and of the results of operations for cancer of the breast from 1889 to 1898 at the Johns Hopkins Hospital. Ann Surg 28: 557-76, 1898. PMID: 17860646.

10 Galimberti V, Vicini E, Corso G, Morigi C, Fontana S, Sacchini $\mathrm{V}$ and Veronesi P: Nipple-sparing and skin-sparing mastectomy: Review of aims, oncological safety and contraindications. Breast 34: S82-S84, 2017. PMID: 28673535. DOI: 10.1016/j.breast. 2017.06.034

11 Freitas R, Oliveira ELC, Pereira RJ, Silva MAC, Esperidião MD, Zampronha RAC, Ribeiro LFJ, Queiroz GS, Jorge EA, Rahal RMS, Ferro JE, Paulinelli RR and Barbosa SFC: Modified radical mastectomy sparing one or both pectoral muscles in the treatment of breast cancer: Intra and postoperative complications. Sao Paulo Med J, 2006. PMID: 17119688. DOI: 10.1590/s1516-31802006000300004

12 Buonomo OC, Varvaras D, Montuori M, Vanni G, Venditti D, Elia S, Santurro L, Granai A V., Petrella G and Rossi P: Onestage immediate implant-based breast reconstruction, using biological matrices after conservative mastectomies: Preliminary experience of the University Hospital of Tor Vergata, Rome. Chir 28: 221-226, 2015.

13 Buonomo OC, Morando L, Materazzo M, Vanni G, Pistilli G, Palla L, Di Pasquali C and Petrella G: Comparison of round 
smooth and shaped micro-textured implants in terms of quality of life and aesthetic outcomes in women undergoing breast reconstruction: a single-centre prospective study. Updates Surg, 2020. PMID: 32062785. DOI: 10.1007/s13304-020-00721-w

14 Calì Cassi L, Vanni G, Petrella G, Orsaria P, Pistolese C, Lo Russo G, Innocenti $\mathrm{M}$ and Buonomo O: Comparative study of oncoplastic versus non-oncoplastic breast conserving surgery in a group of 211 breast cancer patients. Eur Rev Med Pharmacol Sci 20: 2950-2954, 2016. PMID: 27460720.

15 Lee GK and Sheckter CC: Breast reconstruction following breast cancer treatment-2018. JAMA - J Am Med Assoc 320: 12771278, 2018. PMID: 30178060. DOI: 10.1001/jama.2018.12190

16 Nikpayam M, Zeino S, Uzan C, Canlorbe G, Azaïs H and Bichet JC: How I do... a secondary breast reconstruction with lipofilling. Gynecol Obstet Fertil Senol 47: 811-815, 2019. PMID: 31493562. DOI: 10.1016/j.gofs.2019.08.004

17 Nahabedian MY: The bioengineered prosthetic breast reconstruction: Advancements, evidence, and outcomes. Gland Surg 8: 271-282, 2019. PMID: 31328106. DOI: 10.21037/gs. 2018.08.02

18 Gibreel WO, Day CN, Hoskin TL, Boughey JC, Habermann EB and Hieken TJ: Mastectomy and immediate breast reconstruction for cancer in the elderly: a national cancer data base study. J Am Coll Surg 224: 895-905, 2017. PMID: 28238934. DOI: 10.1016/j.jamcollsurg.2016.12.051

19 Laporta R, Sorotos M, Longo B and di Pompeo F: Breast reconstruction in elderly patients: risk factors, clinical outcomes, and aesthetic results. J Reconstr Microsurg 33: 257-267, 2017. PMID: 28061518. DOI: 10.1055/s-0036-1597822

20 Sada A, Day CN, Hoskin TL, Degnim AC, Habermann EB and Hieken TJ: Mastectomy and immediate breast reconstruction in the elderly: Trends and outcomes. Surgery 166: 709-714, 2019. PMID: 31395398. DOI: 10.1016/j.surg.2019.05.055

21 Hamnett KE and Subramanian A: Breast reconstruction in older patients: A literature review of the decision-making process. J Plast Reconstr Aesthetic Surg 69: 1325-1334, 2016. PMID: 27498596. DOI: 10.1016/j.bjps.2016.06.003

22 Fenlon D, Frankland J, Foster CL, Brooks C, Coleman P, Payne S, Seymour J, Simmonds P, Stephens R, Walsh B and Addington-Hall JM: Living into old age with the consequences of breast cancer. Eur J Oncol Nurs 17: 311-316, 2013. PMID: 22947216. DOI: 10.1016/j.ejon.2012.08.004

23 Veronesi U, Salvadori B, Luini A, Greco M, Saccozzi R, del Vecchio M, Mariani L, Zurrida $S$ and Rilke F: Breast conservation is a safe method in patients with small cancer of the breast. Long-term results of three randomised trials on 1,973 patients. Eur J Cancer, 1995. PMID: 7488404. DOI: 10.1016/ 0959-8049(95)00271-j.

24 Veronesi U, Paganelli G, Viale G, Galimberti V, Luini A, Zurrida S, Robertson C, Sacchini V, Veronesi P, Orvieto E, De Cicco C, Intra $\mathrm{M}$ and Tosi $\mathrm{G}$ : Sentinel lymph node biopsy and axillary dissection in breast cancer: Results in a large series. J Natl Cancer Inst, 1999. PMID: 10050871. DOI: 10.1093/jnci/ 91.4.368

25 Bonzano E, Belgioia L, Polizzi G, Siffredi G, Fregatti P, Friedman D, Garelli S, Gusinu M, Vaccara EML, Guenzi M and Corvò R: Simultaneous integrated boost in once-weekly hypofractionated radiotherapy for breast cancer in the elderly: preliminary evidence. In Vivo 33: 1985-1992, 2019. PMID: 31662528. DOI: 10.21873/invivo.11694
26 Buonomo O, Granai A V, Felici A, Piccirillo R, De Liguori Carino N, Guadagni F, Polzoni M, Mariotti S, Cipriani C, Simonetti G, Cossu E, Schiaroli S, Altomare V, Cabassi A, Pernazza E, Casciani CU and Roselli M: Day-surgical management of ductal carcinoma in situ (DCIS) of the breast using wide local excision with sentinel node biopsy. Tumori 88: S48-9, 2002. PMID: 12365390. DOI: $10.1177 / 030089160208800342$

27 Buonomo O, Cabassi A, Guadagni F, Piazza A, Felici A, Piccirillo R, Atzei G, Cipriani C, Schiaroli S, Mariotti S, Guazzaroni M, Cossu E, Simonetti G, Pernazza E, Casciani C and Roselli M: Radioguided-surgery of early breast lesions. Anticancer Res 21: 2091-2097, 2001. PMID: 11501831.

28 Calì Cassi L, Biffoli F, Francesconi D, Petrella G and Buonomo $\mathrm{O}$ : Anesthesia and analgesia in breast surgery: the benefits of peripheral nerve block. Eur Rev Med Pharmacol Sci 21: 13411345, 2017. PMID: 28387892.

29 Vanni G, Materazzo M, Perretta T, Meucci R, Anemona L, Buonomo C, Dauri M, Granai AV, Rho M, Ingallinella S, Tacconi $\mathrm{F}$ and Ambrogi $\mathrm{V}$ : Impact of awake breast cancer surgery on postoperative lymphocyte responses. In Vivo 33: 1879-1884, 2019. PMID: 31662515. DOI: 10.21873/invivo. 11681

30 Orsaria P, Chiaravalloti A, Fiorentini A, Pistolese C, Vanni G, Granai AV, Varvaras D, Danieli R, Schillaci O, Petrella G and Buonomo OC: PET Probe-guided surgery in patients with breast cancer: Proposal for a methodological approach. In Vivo 31: 101-110, 2017. PMID: 28064227. DOI: 10.21873/invivo.11031

31 Vanni G, Tacconi F, Sellitri F, Ambrogi V, Mineo TC and Pompeo E: Impact of awake videothoracoscopic surgery on postoperative lymphocyte responses. Ann Thorac Surg 90: 973978, 2010. PMID: 20732526. DOI: 10.1016/j.athoracsur. 2010.04.070

32 Mineo TC, Sellitri F, Vanni G, Gallina FT and Ambrogi V: Immunological and inflammatory impact of non-intubated lung metastasectomy. Int J Mol Sci 18, 2017. PMID: 28686211. DOI: 10.3390/ijms 18071466

33 Dominici L, Hu J, King T, Ruddy K, Tamimi R, Peppercorn J, Schapira L, Borges V, Come S, Warner E, Partridge A and Rosenberg S: Abstract GS6-06: Local therapy and quality of life outcomes in young women with breast cancer. American Association for Cancer Research (AACR). 2018 San Antonio Breast Cancer Symposium; December 4-8, 2018; San Antonio, TX, USA. Abstract No: GS6-06, 2019. DOI: 10.1158/15387445.SABCS18-GS6-06

34 Pilewskie $M$ and Morrow M: Margins in breast cancer: How much is enough? Cancer 124: 1335-1341, 2018. PMID: 29338088. DOI: $10.1002 /$ cncr.31221

35 Langhans L, Jensen MB, Talman MLM, Vejborg I, Kroman N and Tvedskov TF: Reoperation rates in ductal carcinoma in situ vs invasive breast cancer after wire-guided breast-conserving surgery. JAMA Surg 152: 378-384, 2017. PMID: 28002557. DOI: $10.1001 /$ jamasurg.2016.4751

36 Moran MS, Schnitt SJ, Giuliano AE, Harris JR, Khan SA, Horton J, Klimberg S, Chavez-MacGregor M, Freedman G, Houssami N, Johnson PL and Morrow M: Society of Surgical Oncology-American Society for Radiation Oncology consensus guideline on margins for breast-conserving surgery with wholebreast irradiation in stages I and II invasive breast cancer. J Clin Oncol 32: 1507-1515, 2014. PMID: 24516019. DOI: 10.1200/ JCO.2013.53.3935 
37 Morrow M, Van Zee KJ, Solin LJ, Houssami N, ChavezMacGregor M, Harris JR, Horton J, Hwang S, Johnson PL, Marinovich ML, Schnitt SJ, Wapnir I and Moran MS: Society of Surgical Oncology-American Society for Radiation Oncology-American Society of Clinical Oncology consensus guideline on margins for breast-conserving surgery with wholebreast irradiation in ductal carcinoma in situ. J Clin Oncol 34: 4040-4046, 2016. PMID: 27538810. DOI: 10.1016/j.prro. 2016.06.011

38 Pukancsik D, Kelemen P, Újhelyi M, Kovács E, Udvarhelyi N, Mészáros N, Kenessey I, Kovács T, Kásler M and Mátrai Z: Objective decision making between conventional and oncoplastic breast-conserving surgery or mastectomy: An aesthetic and functional prospective cohort study. Eur J Surg Oncol 43: 303-310, 2017. PMID: 28069398. DOI: 10.1016/ j.ejso.2016.11.010

39 Veronesi U, Boyle P, Goldhirsch A, Orecchia R and Viale G: Breast cancer. Lancet 365: 1727-1741, 2005. PMID: 15894099. DOI: 10.1016/S0140-6736(05)66546-4

40 Bounous VE, Novara L, Scicchitano F, Villasco A, Maggiorotto F, Ponzone R and Biglia N: A retrospective analysis on 197 cases of breast cancer local recurrence: Biology, treatment, and prognosis. Breast J, 2019. PMID: 31763725. DOI: 10.1111/tbj. 13698

41 Kozlowski J, Kozlowska A and Kocki J: Breast cancer metastasis - insight into selected molecular mechanisms of the phenomenon. Postepy Hig Med Dosw (Online) 69: 447-451, 2015. PMID: 25897105. DOI: 10.5604/17322693.1148710

42 Anderson SJ, Wapnir I, Dignam JJ, Fisher B, Mamounas EP, Jeong JH, Geyer CE, Wickerham DL, Costantino JP and Wolmark N: Prognosis after ipsilateral breast tumor recurrence and locoregional recurrences in patients treated by breastconserving therapy in five national surgical adjuvant breast and bowel project protocols of node-negative breast cancer. J Clin Oncol, 2009. PMID: 19349544. DOI: 10.1200/JCO.2008. 19.8424

43 Karam AK: Breast cancer posttreatment surveillance: diagnosis and management of recurrent disease. Clin Obstet Gynecol, 2016. PMID: 27681690. DOI: 10.1097/GRF.0000000000000243

44 Fisher B, Anderson S, Bryant J, Margolese RG, Deutsch M, Fisher ER, Jeong JH and Wolmark N: Twenty-year follow-up of a randomized trial comparing total mastectomy, lumpectomy, and lumpectomy plus irradiation for the treatment of invasive breast cancer. N Engl J Med 347: 1233-1241, 2002. PMID: 12393820. DOI: $10.1056 /$ NEJMoa022152

45 Van Laar C, Van Der Sangen MJC, Poortmans PMP, Nieuwenhuijzen GAP, Roukema JA, Roumen RMH, TjanHeijnen VCG and Voogd AC: Local recurrence following breastconserving treatment in women aged 40 years or younger: Trends in risk and the impact on prognosis in a population-based cohort of 1143 patients. Eur J Cancer 73: 734-744, 2013. PMID: 23800672. DOI: 10.1016/j.ejca.2013.05.030

46 Veronesi U, Orecchia R, Maisonneuve P, Viale G, Rotmensz N, Sangalli C, Luini A, Veronesi P, Galimberti V, Zurrida S, Leonardi MC, Lazzari R, Cattani F, Gentilini O, Intra M, Caldarella $\mathrm{P}$ and Ballardini B: Intraoperative radiotherapy versus external radiotherapy for early breast cancer (ELIOT): A randomised controlled equivalence trial. Lancet Oncol 14: 12691277, 2013. PMID: 24225155. DOI: 10.1016/S14702045(13)70497-2
47 Voogd AC, Van Oost FJ, Rutgers EJT, Elkhuizen PHM, Van Geel AN, Scheijmans LJEE, Van Der Sangen MJC, Botke G, Hoekstra CJ, Jobsen JJ, Van De Velde CJH, Von Meyenfeldt MF, Tabak JM, Peterse JL, Van De Vijver MJ, Coebergh JWW and Van Tienhoven G: Long-term prognosis of patients with local recurrence after conservative surgery and radiotherapy for early breast cancer. Eur J Cancer 41: 2637-2644, 2005. PMID: 16115758. DOI: 10.1016/j.ejca.2005.04.040

48 Dalberg K, Mattsson A, Sandelin K and Rutqvist LE: Outcome of treatment for ipsilateral breast tumor recurrence in early-stage breast cancer. Breast Cancer Res Treat 49: 69-78, 1998. PMID: 9694613. DOI: 10.1023/a:1005934513072

49 Fisher B, Montague E, Redmond C, Barton B, Borland D, Fisher ER, Deutsch M, Schwarz G, Margolese R, Donegan W, Volk H, Konvolinka C, Gardner B, Cohn I, Lesnick G, Cruz AB, Lawrence W, Nealon T, Butcher H, Lawton R and Investigators $\mathrm{ON}$ : Comparison of radical mastectomy with alternative treatments for primary breast cancer: A first report of results from a prospective randomized clinical trial. Cancer, 1977. PMID: 326381. DOI: 10.1002/1097-0142(197706)39:6<2827 ::aid-cncr2820390671>3.0.co;2-i

50 Buonomo OC, Caredda E, Portarena I, Vanni G, Orlandi A, Bagni C, Petrella G, Palombi L and Orsaria P: New insights into the metastatic behavior after breast cancer surgery, according to well-established clinicopathological variables and molecular subtypes. PLoS One 12: e0184680, 2017. PMID: 28922402. DOI: 10.1371 /journal.pone. 0184680

51 Orsaria P, Caredda E, Genova F, Materazzo M, Capuano I, Vanni G, Granai AV, de Majo A, Portarena I, Sileri P, Petrella G, Palombi L and Buonomo OC: Additional nodal disease prediction in breast cancer with sentinel lymph node metastasis based on clinicopathological features. Anticancer Res 38: 21092117, 2018. PMID: 29599329. DOI: 10.21873/anticanres.12451

52 Roselli M, Guadagni F, Buonomo O, Belardi A, Ferroni P, Diodati A, Anselmi D, Cipriani C, Casciani CU, Greiner J and Schlom J: Tumor markers as targets for selective diagnostic and therapeutic procedures. Anticancer Res 16: 2187-2192, 1996. PMID: 8694541.

53 Ferroni P, Palmirotta R, Spila A, Martini F, Formica V, Portarena I, Del Monte G, Buonomo O, Roselli M and Guadagni F: Prognostic value of carcinoembryonic antigen and vascular endothelial growth factor tumor tissue content in colorectal cancer. Oncology 71: 176-184, 2007. PMID: 17652942. DOI: $10.1159 / 000106072$

54 Ferroni P, Roselli M, Spila A, D’Alessandro R, Portarena I, Mariotti S, Palmirotta R, Buonomo O, Petrella G and Guadagni F: Serum sE-selectin levels and carcinoembryonic antigen mRNA-expressing cells in peripheral blood as prognostic factors in colorectal cancer patients. Cancer 116: 2913-2921, 2010. PMID: 20336782. DOI: 10.1002/cncr.25094

55 Buonomo OC, Grasso A, Pistolese CA, Anemona L, Portarena I, Meucci R, Morando L, Deiana C, Materazzo M and Vanni G: Evaluation of concordance between histopathological, radiological and biomolecular variables in breast cancer neoadjuvant treatment. Anticancer Res 40: 281-286, 2020. PMID: 31892577. DOI: 10.21873/anticanres. 13950

56 Cancer Research UK: Breast cancer survival statistics. 20052009, 2014. Available at: https://www.cancerresearchuk.org/ health-professional/cancer-statistics/statistics-by-cancertype/breast-cancer/survival 
57 Crane R and Baker CR: Breast cancer treatment. Nurse Pract Forum 10: 145-153, 1999. PMID: 10614359.

58 Jonczyk MM, Jean J, Graham R and Chatterjee A: Trending towards safer breast cancer surgeries? Examining acute complication rates from a 13-year nsqip analysis. Cancers (Basel) 11, 2019. PMID: 30795637. DOI: 10.3390/ cancers 11020253

59 Giorgi Rossi P, Carrozzi G, Federici A, Mancuso P, Sampaolo L and Zappa M: Invitation coverage and participation in Italian cervical, breast and colorectal cancer screening programmes. J Med Screen 25: 17-23, 2018. PMID: 28614991. DOI: 10.1177/ 0969141317704476

60 Kabat GC, Ginsberg M, Sparano JA and Rohan TE: Risk of recurrence and mortality in a multi-ethnic breast cancer population. J Racial Ethn Heal Disparities 4: 1181-1188, 2017. PMID: 28004356 DOI: 10.1007/s40615-016-0324-y

61 Lebel S, Beattie S, Arés I and Bielajew C: Young and worried: Age and fear of recurrence in breast cancer survivors. Health Psychol 32: 695-705, 2013. PMID: 23088176. DOI: 10.1037/ a0030186

62 Ribnikar D, Ribeiro JM, Pinto D, Sousa B, Pinto AC, Gomes E, Moser EC, Cardoso MJ and Cardoso F: Breast cancer under age 40: a different approach. Curr Treat Options Oncol 16: 16, 2015. PMID: 25796377. DOI: $10.1007 / \mathrm{s} 11864-015-0334-8$

63 Diab SG, Elledge RM and Clark GM: Tumor characteristics and clinical outcome of elderly women with breast cancer. J Natl Cancer Inst 92: 550-556, 2000. PMID: 10749910. DOI: $10.1093 /$ jnci/92.7.550

64 Comen EA, Norton L and Massagué J: Breast cancer tumor size, nodal status, and prognosis: Biology trumps anatomy. J Clin Oncol 29: 2610-2612, 2011. PMID: 21606411. DOI: 10.1200/ JCO.2011.36.1873

65 Mohammed H, Russell IA, Stark R, Rueda OM, Hickey TE, Tarulli GA, Serandour AAA, Birrell SN, Bruna A, Saadi A, Menon S, Hadfield J, Pugh M, Raj G V., Brown GD, D'Santos C, Robinson JLL, Silva G, Launchbury R, Perou CM, Stingl J, Caldas C, Tilley WD and Carroll JS: Progesterone receptor modulates ER $\alpha$ action in breast cancer. Nature 526: 144, 2015. PMID: 26245370. DOI: 10.1038/nature14959

66 Yip $\mathrm{CH}$ and Rhodes A: Estrogen and progesterone receptors in breast cancer. Futur Oncol 10: 2293-2301, 2014. PMID: 25471040. DOI: $10.2217 /$ fon. 14.110

67 Tandon AK, Clark GM, Chamness GC, Ullrich A and McGuire WL: HER-2/neu oncogene protein and prognosis in breast cancer. J Clin Oncol 7: 1120-1128, 1989. PMID: 2569032. DOI: 10.1200/JCO.1989.7.8.1120
68 Yarden Y: Biology of HER2 and its importance in breast cancer. Oncology 61: 1-13, 2001. PMID: 11694782. DOI: 10.1159/ 000055396

69 Nishimura R, Osako T, Okumura Y, Tashima R, Toyozumi Y and Arima N: Changes in the ER, PgR, HER2, p53 and Ki-67 biological markers between primary and recurrent breast cancer: Discordance rates and prognosis. World J Surg Oncol 9: 131, 2011. PMID: 22004841. DOI: 10.1186/1477-7819-9-131

70 Nishimura R, Osako T, Okumura Y, Hayashi M, Totoyozumi Y and Arima N: Ki-67 as a prognostic marker according to breast cancer subtype and a predictor of recurrence time in primary breast cancer. Exp Ther Med 1: 747-754, 2010. PMID: 22993598. DOI: $10.3892 / \mathrm{etm} .2010 .133$

71 Foulkes WD, Reis-Filho JS and Narod SA: Tumor size and survival in breast cancer- A reappraisal. Nat Rev Clin Oncol 7: 348-353, 2010. PMID: 20309006. DOI: 10.1038/nrclinonc. 2010.39

72 Morrow M, Harris JR and Schnitt SJ: Surgical margins in lumpectomy for breast cancer - Bigger is not better. N Engl $\mathrm{J}$ Med 367: 79-82, 2012. PMID: 22762325. DOI: 10.1056/ NEJMsb1202521

73 Carter D: Margins of "Lumpectomy" for breast cancer. Hum Pathol 17: 330-332, 1986. PMID: 3957334. DOI: 10.1007/ BF02966893

74 Graham RA, Homer MJ, Katz J, Rothschild J, Safaii H and Supran S: The pancake phenomenon contributes to the inaccuracy of margin assessment in patients with breast cancer. Am J Surg 184: 89-93, 2002. PMID: 12169349. DOI: 10.1016/s0002-9610(02)00902-9

75 Holland R, Veling SHJ, avunac $M$ and Hendriks JHCL: Histologic multifocality of tis, T1-2 breast carcinomas implications for clinical trials of breast-conserving surgery. Cancer 56: 979-990, 1985. PMID: 2990668. DOI: 10.1002/10970142(19850901)56:5<979::aid-cncr2820560502>3.0.co;2-n

76 Kunkler IH, Williams LJ, Jack WJL, Cameron DA and Dixon JM: Breast-conserving surgery with or without irradiation in women aged 65 years or older with early breast cancer (PRIME II): A randomised controlled trial. Lancet Oncol 16: 266-273, 2015. PMID: 25637340. DOI: 10.1016/S1470-2045(14)71221-5

Received February 20, 2020

Revised March 12, 2020

Accepted March 13, 2020 